\title{
Wszczepialne kardiowertery-defibrylatory - czy test skuteczności defibrylacji jest jeszcze potrzebny?
}

\author{
Implantable cardioverter-defibrillators \\ - is defibrillation efficacy testing still necessary?
}

\author{
Danuta Łoboda ${ }^{1,2}$, Magdalena Dąbrowska ${ }^{2}$, Michał Gibiński ${ }^{1,2}, K^{2}$ rysztof S. Gołba ${ }^{1,2}$ \\ ${ }^{1}$ Klinika Elektrokardiologii i Niewydolności Serca Wydziału Nauk o Zdrowiu Śląskiego Uniwersytetu Medycznego w Katowicach \\ ${ }^{2}$ Oddział Elektrokardiologii Samodzielnego Publicznego Szpitala Klinicznego nr 7 \\ Śląskiego Uniwersytetu Medycznego w Katowicach, Górnośląskie Centrum Medyczne im. prof. Leszka Gieca
}

\section{Streszczenie}

Test defibrylacji (DT) od ponad 20 lat stanowił integralną część procedury implantacji wszczepialnych kardiowerterów-defibrylatorów (ICD). Indukcja migotania komór w czasie DT ma na celu potwierdzenie adekwatnego marginesu bezpieczeństwa pomiędzy maksymalną energią generowaną przez ICD, a energią defibrylacji wymaganą dla przerwania zagrażających życiu arytmii komorowych. Aktualnie postęp technologiczny sprawił, że skuteczność kliniczna terapii antyarytmicznej ICD sięga 90\% co wpływa na stały trend do rezygnacji z wykonywania DT. Tematem artykułu są aktualne pytania związane z problemem podwyższonego progu defibrylacji (DFT) oraz koniecznością i bezpieczeństwem dalszego rutynowego wykonywania DT.

Słowa kluczowe: próg defibrylacji, test defibrylacji, wszczepialny kardiowerter-defibrylator

Folia Cardiologica 2016; 11, 3: 247-251

\section{Wstęp}

Każdego roku na świecie implantuje się 400 tysięcy kardiowerterów-defibrylatorów (ICD, implantable cardioverter-defibrillator) serca w prewencji pierwotnej i wtórnej nagłego zgonu sercowego (SCD, sudden cardiac death) [1]. Skuteczność i bezpieczeństwo leczenia za pomocą ICD zależy od sprawności urządzenia w zakresie detekcji i terminacji zagrażających życiu arytmii komorowych. Oceny efektywności defibrylacji migotania komór (VF, ventricular fibrillation) oraz marginesu bezpieczeństwa defibrylacji (tj. rezerwy między energią wymaganą dla przerwania VF a maksymalną energią generowaną przez implantowany model ICD) dokonuje się podczas śródoperacyjnego testu defibrylacji (DT, defibrillation testing) [2]. Ponadto w czasie DT oceniana jest integralność elektrod, prawidłowość połączeń pomiędzy elektrodami a obudową urządzenia, a także czas i skuteczność ładowania kondensatorów [2, 3].

\section{Na czym polega test defibrylacji?}

Przeprowadzenie DT polega na indukcji elektrycznej VF, które jest automatycznie rozpoznawane i przerywane przez wszczepiony ICD. W celu indukcji VF wykorzystuje się niskoenergetyczne wyładowanie w strefie ranliwej załamka T (szok synchronizowany z załamkiem T) lub szybką stymulację komór wiązką impulsów o częstotliwości $50 \mathrm{~Hz}$ [3]. Procedura wymaga krótkotrwałego znieczulenia ogólnego. W przypadku, gdy zastosowanie maksymalnej energii generowanej przez ICD jest niewystarczające do przerwania VF lub gdy VF jest przerywane z zastosowaniem energii przekraczającej ustalony na $10 \mathrm{~J}$ margines bezpieczeń-

Adres do korespondencji: lek. Danuta Łoboda, Klinika Elektrokardiologii i Niewydolności Serca, Wydział Nauk o Zdrowiu, Śląski Uniwersytet Medyczny w Katowicach, e-mail: dana.loboda@gmail.com 
stwa, mówi się o podwyższonym progu defibrylacji (DFT, defibrillation threshold) [4].

\section{Jakie są konsekwencje uzyskania zbyt wysokiego progu defibrylacji?}

Brak adekwatnego marginesu bezpieczeństwa poddaje w wątpliwość kliniczną skuteczność ICD i skłania do podejmowania prób obniżenia minimalnej energii defibrylacji. W pierwszej kolejności rozpatruje się odwracalne przyczyny tej sytuacji, takie jak: odma opłucnowa, wysięk osierdziowy, zaburzenia elektrolitowe i metaboliczne, zaostrzenie niewydolności serca oraz wpływ leków antyarytmicznych i anestetyków [5]. U chorych ze znacznie obniżoną frakcją wyrzutową lewej komory (LVEF, left-ventricular ejection fraction) przyczyną czasowego podwyższenia DFT mogą być również powtarzane indukcje i defibrylacje VF [5].

Następnym krokiem jest przeprogramowanie parametrów ICD wpływających na wysokość DFT poprzez zmianę kierunku (polarności) impulsu defibrylacyjnego w pierwszej fazie defibrylacji [6] lub odchylenie jego wektora (przez „odłączenie", dzięki przeprogramowaniu urządzenia, bieguna umieszczonego w żyle głównej górnej [SVC, superior vena cava] lub "odłączenie” obudowy urządzenia w przypadku implantowanej elektrody dwubiegunowej) [3, 7]. W części urządzeń możliwa jest zmiana procentowego spadku wyjściowego napięcia kondensatora oraz czasu trwania drugiej fazy impulsu [3].

Przy znacznej rozstrzeni lewej komory (LV, left ventricle) użyteczna może być wymiana elektrody jednobiegunowej na dwubiegunową (z dwiema spiralami [coilami] defibrylującymi umieszczonymi w prawej komorze oraz w SVC) lub dodanie elektrody „pływającej” umieszczanej w SVC, co zapewnia objęcie większej masy LV impulsem defibrylującym [7]. W trudnych przypadkach zdecydowaną zmiane wektora defibrylacji można uzyskać poprzez umieszczenie elektrody defibrylującej podskórnie, w zatoce wieńcowej lub w żyle nieparzystej (vena azygos) [8-10]. W przypadku elektrody podskórnej biegun defibrylujący znajduje się po lewej stronie klatki piersiowej na wysokości IV do VI żebra, co sprawia, że podczas defibrylacji impuls elektryczny obejmuje duży obszar LV od strony bocznej [3, 9]. Z kolei elektrody defibrylujące wprowadzane przezżylnie do zatoki wieńcowej lub żyły nieparzystej i zlokalizowane za sercem umożliwiają objęcie energią defibrylującą tylno-bocznej ściany LV $[8,10]$.

Szacuje się, że poprzez przeprogramowanie urządzenia można osiągnąć zmniejszenie DFT o 4-6 J [3]. Doszczepienie elektrody podskórnej lub do żyły nieparzystej może zmniejszyć DFT o około $10 \mathrm{~J}[8,9]$. U pacjentów z czynnikami ryzyka wystąpienia wysokiego DFT rozsądne może być planowe implantowanie ICD o wyższej energii defibrylacji równej $40 \mathrm{~J}$ [3].

\section{Wątpliwości związane z rutynowym} wykonywaniem testu defibrylacji

Od lat podnoszone są liczne wątpliwości związane z rutynowym wykonywaniem DT:

- zmienił się rodzaj implantowanych urządzeń i stosowana przez nie terapia - nowoczesne ICD pozwalaja na uzyskiwanie DFT niższych od maksymalnej energii defibrylacji średnio o 25 J dzięki wykorzystaniu dwufazowego impulsu defibrylacyjnego o programowalnym wektorze i zastosowaniu aktywnej obudowy (active can) [11]. Ponadto urządzenia te wykorzystują również inne formy terapii niż wyładowanie wysokoenergetyczne. Monomorficzny częstoskurcz komorowy (VT, ventricular tachycardia), który jest najczęstszym rodzajem arytmii komorowej rejestrowanej przez ICD, może być przerwany nieodczuwalną przez pacjenta stymulacją antytachyarytmiczną (ATP, anti-tachycardia pacing) za pomocą wiązki szybkich impulsów o niskiej energii $[12,13]$. W badaniu Prospective Randomized Multicenter Trial of Empirical Antitachycardia Pacing Versus Shocks for Spontaneous Rapid Ventricular Tachycardia in Patients With Implantable Cardioverter-Defibrillators (Pain Free) [13] tylko 10\% arytmii komorowych miało częstość większą niż 250/min („strefa VF”) i bezwzględnie wymagało defibrylacji, a adekwatne zaprogramowanie parametrów ATP umożliwiło przerwanie aż $80 \%$ szybkich VT (o częstości 200-250/min w strefie „fast-VT”);

- zmienił się typ pacjentów, którym implantuje się ICD - większość urządzeń jest implantowana w prewencji pierwotnej SCD, co wymusza nowe spojrzenie na stosunek korzyści do ryzyka DT w profilaktyce. W dużych badaniach klinicznych Multicenter Automatic Defibrillator Implantation Trial II (MADIT-II) [14] i Sudden Cardiac Death in Heart Failure Trial (SCD-HeFT) [15] w czasie 2-4-letniego okresu obserwacji tylko 30\% chorych z implantowanym ICD doświadczyło arytmii komorowej wymagającej defibrylacji. Rośnie też liczba chorych kwalifikowanych do wszczepienia kardiowerterów-defibrylatorów z funkcją resynchronizującą (CRT-D, cardiac resynchronization therapy with defibrillator function). Ta grupa pacjentów, z uwagi na niższe średnie wartości LVEF oraz zaawansowaną niewydolność serca, może nie tolerować wyindukowanego VF oraz częściej doświadczać związanych z DT powikłań okołooperacyjnych [16];

- wątpliwości budzą fizjologiczne różnice pomiędzy indukowanym a spontanicznym VF - skuteczność kliniczna pierwszego wyładowania ICD w reakcji na VT/VF (szacowana na 83-93\%) [2, 17, 18] jest niższa niż skuteczność szoku podczas DT (91-99\%) [2, 18]. Oznacza to, że indukowane podczas testu defibrylacji VF nie jest dobrym modelem spontanicznej arytmii i nie wszystkie czynniki niekorzystnie wpływające na 
skuteczność defibrylacji i detekcję pobudzeń kardiotopowych (jak niedokrwienie, zaburzenia elektrolitowe, wpływ leków) da się odtworzyć podczas testu $[2,18]$;

- co istotne, udowodniono, że wykonanie testu defibrylacji i jego wynik nie wpływają na rokowanie pacjenta w obserwacji odległej - Blatt i wsp. [17] w retrospektywnej analizie obejmującej ponad 2400 chorych włączonych do badania SCD-HeFT wykazali, że zarówno śmiertelność pacjentów, jak i skuteczność pierwszego wyładowania ICD nie różniła się między grupami z marginesem DFT poniżej $10 \mathrm{~J}$ i DFT powyżej $10 \mathrm{~J}$. Również Stavrakis i wsp. [19] w metaanalizie obejmującej 8 dużych badań (łącznie 5020 pacjentów ze średnim czasem obserwacji wynoszącym 24 miesiące) nie wykazali, aby wykonanie DT w czasie implantacji ICD miało wpływ na śmiertelność ogólną i z przyczyn arytmicznych w obserwacji odległej;

- test defibrylacji może wiązać się z ryzykiem powikłań - potencjalne ryzyko powikłań DT wynika łącznie ze wszystkich zasadniczych elementów protokołu [2]. Wyindukowane VF, wyładowanie wysokoenergetyczne, a także konieczność przeprowadzenia znieczulenia ogólnego mogą prowadzić do rozkojarzenia elektryczno-mechanicznego oraz opornego na terapię VF [20], uszkodzenia miokardium ze wzrostem stężenia troponin sercowych [21] oraz upośledzeniem czynności skurczowej w efekcie ogłuszenia mięśnia sercowego [22], hipoperfuzji ośrodkowego układu nerwowego [23] oraz powikłań zakrzepowo-zatorowych w konsekwencji nieadekwatnej antykoagulacji [24]. Największe badanie obserwacyjne (19 067 zabiegów implantacji ICD) oceniające ryzyko wykonania DT przeprowadzili Birne i wsp. w Kanadzie [24]. W związku z wykonaniem DT 27 chorych doświadczyło zatrzymania krążenia wymagającego przedłużonej resuscytacji (5 z tych chorych zmarło lub doznało nieodwracalnego uszkodzenia ośrodkowego układu nerwowego), a 5 chorych przebyło związany z procedurą udar mózgu. Ryzyko zgonu oraz potencjalnie śmiertelnych powikłań związanych z wykonaniem śródoperacyjnego DT oceniono na 0,1-0,2\%. Statystycznie „małe” ryzyko jest jednak nie do pominięcia w przypadku indywidualnego pacjenta;

- nieskuteczny test defibrylacji niesie za sobą dodatkowe ryzyko związane z próbami obniżenia DFT - nieskuteczny DT wymusza modyfikacje systemu ICD, co zwiększa o 20\% odsetek powikłań okołozabiegowych i przedłużonej hospitalizacji oraz o 50\% śmiertelność wewnątrzszpitalną [25]. Długi czas zabiegu zwiększa ryzyko zakażenia, przedłużony czas znieczulenia ilość podanych anestetyków, powtarzanie DT - ryzyko związane z wyładowaniami wysokoenergetycznymi, a implantacja nowych elektrod - liczbę powikłań zwią- zanych z punkcją, tunelizacją i innymi procedurami operacyjnymi [3].

\section{Jak postępuje się w praktyce?}

Odzwierciedleniem tych wątpliwości jest stały trend do rezygnacji z wykonywania DT podczas implantacji ICD. Według danych European Heart Rhythm Association [1] w 2014 roku jedynie $20 \%$ ośrodków wykonywało DT u wszystkich chorych. Kolejnych $20 \%$ ośrodków wykonywało go tylko u pacjentów z szacowanym wysokim ryzykiem podwyższonego DFT. Nawet u chorych z ICD implantowanym w prewencji wtórnej nagłego zgonu sercowego DT wykonywany był każdorazowo jedynie w 35\% ośrodków.

\section{Czy istnieją przesłanki do dalszego wykonywania testu defibrylacji?}

Dotychczas najważniejszym argumentem przemawiającym za wykonywaniem DT w praktyce klinicznej był fakt, że w randomizowanych badaniach oceniających skuteczność ICD w redukcji umieralności stanowił nieodłączną część protokołu implantacji, jako potwierdzenie prawidłowego działania implantowanego urządzenia [14, 26, 27]. Jak dotąd nie było dowodów z randomizowanych badań klinicznych pozwalających od tej procedury odstąpić. Odpowiedzi na pytanie, czy rutynowo wykonywać DT, dostarczyły dopiero wyniki trzech dużych badań z randomizacją: Safety of Two Strategies of ICD Management at Implantation (SAFE-ICD) - badanie włoskie, 2120 pacjentów, około 50\% urządzeń z maksymalną energią defibrylacji $40 \mathrm{~J}$ [28], The Shockless IMPLant Evaluation (SIMPLE) - badanie przeprowadzone w 18 krajach, w tym w Polsce, 2500 pacjentów, energia pierwszego wyładowania ICD 31 J [16], i The NO Regular Defibrillation testing In Cardioverter Defibrillator Implantation (NORDIC ICD) - europejskie badanie wieloośrodkowe, 1077 pacjentów, w tym 356 pacjentów z CRT-D, energia pierwszego wyładowania $40 \mathrm{~J}$ [29]. We wszystkich tych badaniach, w których brali udział chorzy po implantacji urządzeń w prewencji pierwotnej i wtórnej, nie wykazano istotnej statystycznie różnicy w występowaniu zgonów z przyczyn arytmicznych i przypadków nieskutecznej terapii ICD pomiędzy grupami pacjentów, u których wykonano i nie wykonano testu weryfikacji skuteczności defibrylacji. Warto zwrócić uwage na bardzo wysoką, sięgającą 94-97\%, skuteczność pierwszego wyładowania nowoczesnych urządzeń o energii $40 \mathrm{~J}$ raportowaną w badaniu NORDIC ICD.

Otwarte pozostaje pytanie, czy wyniki powyższych badań są reprezentatywne dla całej populacji. Dotyczy to przede wszystkim grup pacjentów słabo reprezentowanych w badaniach i rejestrach: młodych, z układem implantowanym po prawej stronie, z elektrodą podskórną, w zatoce 
wieńcowej czy żyle nieparzystej, z rzadszymi schorzeniami, jak kardiomiopatia przerostowa, kanałopatie, sarkoidoza i inne [30].

Badacze amerykańscy, analizując metodą regresji logistycznej dane pochodzące z National Cardiovascular Data Registry [25] (132 477 chorych z implantowanym w latach 2010-2012 ICD), podjęli próbę odpowiedzi na pytanie, czy można na podstawie cech klinicznych wyodrębnić chorych o wysokim ryzyku podwyższonego DFT. Stworzona przez nich skala ryzyka obejmuje 8 elementów: wiek powyżej 70. roku życia (1 punkt), płeć męska (1 punkt), rasa: czarna (4 punkty), latynoska (2 punkty), inna (1 punkt), klasa wydolności według klasyfikacji New York Heart Association (NYHA): III (1 punkt) lub IV (3 punkty), nieniedokrwienna etiologia niewydolności serca (2 punkty), schyłkowa niewydolność nerek wymagająca dializ (3 punkty), prewencja wtórna SCD (1 punkt), typ ICD: jednojamowy (2 punkty) lub dwujamowy (1 punkt). Niskim ryzykiem podwyższonego DFT (prawdopodobieństwo 6,8\%) charakteryzowali się w tym badaniu chorzy z punktacją mniejszą lub równą 3 punkty, wysokim (prawdopodobieństwo 14,9\%) - chorzy z punktacją większą lub równą 7 punktów. Uwagę zwraca duży wpływ pochodzenia etnicznego pacjentów na wynik punktacji.
Istnieje zatem pilna potrzeba walidacji skali w Europie lub przeprowadzenia podobnej analizy danych pochodzących z populacji europejskiej.

\section{Podsumowanie}

Nadal nie jest znana odpowiedź na wszystkie pytania dotyczące testu defibrylacji. Z pewnością wyniki szeroko zakrojonych randomizowanych badań dadzą podstawę (przekutą w standardy medyczne) do rezygnacji z DT u większości pacjentów kwalifikowanych do pierwszorazowej implantacji ICD/CRT-D po lewej stronie. Pozostaje jednak (słabo jeszcze zdefiniowana) grupa chorych z wysokim ryzykiem podwyższonego DFT, w której DT nadal warto wykonać. Być może są to kandydaci do planowego zastosowania urządzeń o maksymalnej dostępnej energii defibrylacji. Na odpowiedź zasługuje także pytanie, czy stare kryteria bezpiecznego marginesu defibrylacji przystają do nowych czasów i nowoczesnych ICD. Obecnie pozostaje jeszcze jeden dylemat: jak w świetle aktualnej wiedzy medycznej i powstałych wątpliwości co do bilansu korzyści i ryzyka umożliwić choremu podjęcie świadomej zgody na wykonanie testu defibrylacji?

\section{Abstract}

Defibrillation testing (DT) has been an integral component of implantable cardioverter-defibrillator (ICD) implantation procedure for over the last 20 years. The induction of ventricular fibrillation (VF) during the DT is the accepted method to determine a sufficient safety margin between the maximum shock energy of the ICD and the shock energy required for defibrillation life threatening ventricular arrhythmias. Nowadays, ICD technology has evolved and the likelihood of successful VF defibrillation achieved 90\%, which determines a trend toward ICD implantation without DT. The topic of this article are questions and answers concerning the problems with elevated defibrillation threshold and the appropriateness and safety of routine intraoperative DT.

Key words: defibrillation threshold, defibrillation testing, implantable cardioverter-defibrillator

Folia Cardiologica 2016; 11, 3: 247-251

\section{Piśmiennictwo}

1. Todd D., Bongiorni M.G., Hernandez-Madrid A. i wsp. Scientific Initiative Committee, European Heart Rhythm Association. Standards for device implantation and follow-up: personnel, equipment, and facilities: results of the European Heart Rhythm Association Survey. Europace 2014; 16: 1236-1239.

2. Swerdlow C.D., Russo A.M., Degroot P.J. The Dilemma of ICD Implant Testing. PACE 2007; 30: 675-700.

3. Maciąg A., Przybylski A. Wszczepienie kardiowertera-defibrylatora. W: Przybylski A., Sterliński M. Implantowane kardiowertery-defibrylatory. Wyd. III. Wydawnictwo AiM, Warszawa 2011: 65-83.

4. Barold S.S., Herweg B., Curtis A.B. The Defibrillation Safety Margin of Patients Receiving ICDs: A Matter of Definition. PACE 2005; 28 : 881-882.
5. Swerdlow C., Shivkumar K. Implantable cardioverter-defibrillators: clinical aspects. W: Zipes D., Jalife J. Cardiac electrophysiology, from cell to bedside. W.B. Saunders, Philadelphia 2004: 984-990.

6. Strickberger S.A., Hummel J.D., Horwood L.E. i wsp. Effect of shock polarity on ventricular defibrillation threshold using a transvenous lead system. J. Am. Coll. Cardiol. 1994; 24: 1069-1072.

7. Lewandowski M., Przybylski A., Kraska A., Szwed H. Wysoki próg defibrylacji u chorych z wszczepialnym kardiowerterem-defibrylatorem. Sposoby rozwiązania tego problemu na podstawie doświadczeń własnych. Folia Cardiol. Excerpta 2006; 1: 101-109.

8. Cooper J.A., Latacha M.P., Soto G.E. i wsp. The azygos defibrillator lead for elevated defibrillation thresholds: implant technique, lead stability, and patient series. Pacing Clin. Electrophysiol. 2008; 31: 1405-1410. 
9. Osswald B.R., De Simone R., Most S. i wsp. High defibrillation threshold in patients with implantable defibrillator: how effective is the subcutaneous finger lead? Eur. J. Cardiothorac. Surg. 2009; 35: 489-492.

10. Wilczek R., Świątkowski M., Czepiel A. i wsp. Implantation of additional defibrillation lead into the coronary sinus: an effective method of decreasing defibrillation threshold. Kardiol. Pol. 2011; 69: 1308$-1309$.

11. Russo A.M., Sauer W., Gerstenfeld E.P. i wsp. Defibrillation threshold testing: Is it really necessary at the time of implantable cardioverter-defibrillator insertion? Heart Rhythm 2005; 2: 456-461.

12. Mitra R.L., Hsia H.H., Hook B.G. i wsp. Efficacy of antitachycardia pacing in patients presenting with cardiac arrest. Pacing Clin. Electrophysiol. 1995; 18: 2035-2040.

13. Wathen M.S., DeGroot P.J., Sweeney M.O. i wsp. Prospective Randomized Multicenter Trial of Empirical Antitachycardia Pacing Versus Shocks for Spontaneous Rapid Ventricular Tachycardia in Patients With Implantable Cardioverter-Defibrillators. Pacing Fast Ventricular Tachycardia Reduces Shock Therapies (PainFREE Rx II) Trial Results. Circulation 2004; 110: 2591-2596.

14. Moss A.J., Zareba W., Hall W.J. i wsp. Multicenter Automatic Defibrillator Implantation Trial II Investigators. Prophylactic implantation of a defibrillator in patients with myocardial infarction and reduced ejection fraction. N. Engl. J. Med. 2002; 346: 877-883.

15. Packer D.L., Prutkin J.M., Hellkamp A.S. i wsp. Impact of Implantable Cardioverter-Defibrillator, Amiodarone, and Placebo on the Mode of Death in Stable Patients With Heart Failure. Analysis From the Sudden Cardiac Death in Heart Failure Trial. Circulation 2009; 120 : 2170-2176.

16. Healey J.S., Hohnloser S.H., Glikson M. i wsp. Cardioverter defibrillator implantation without induction of ventricular fibrillation: a single-blind, non-inferiority, randomized controlled trial (SIMPLE). Lancet 2015; 385: 785-791.

17. Blatt J.A., Poole J.E., Johnson G.W. i wsp. No benefit from defibrillation-threshold testing in the SCD-HeFT (Sudden Cardiac Death in Heart Failure Trial). J. Am. Coll. Cardiol. 2008; 52: 551-556.

18. Viskin S., Rosso R. The top 10 reasons to avoid defibrillation threshold testing during ICD implantation. Heart Rhythm 2008; 5: 391-393.

19. Stavrakis S., Patel N.H., Reynolds D.W. Defibrillation Threshold Testing Does Not Predict Clinical Outcomes during Long-Term Follow-Up: A Meta-Analysis. Pacing Clin. Electrophysiol. 2013; 36: 1402-1408.
20. Frame R., Brodman R., Furman S. i wsp. Clinical evaluation of the safety of repetitive intraoperative defibrillation threshold testing. Pacing Clin. Electrophysiol. 1992; 15: 870-877.

21. Semmler V., Biermann J., Haller B. i wsp. ICD Shock, Not Ventricular Fibrillation, Causes Elevation of High Sensitive Troponin T after Defibrillation Threshold Testing - The Prospective, Randomized, Multicentre TropShock-Trial. PLoS One 2015; 10: e0131570.

22. Steinbeck G., Dorwarth U., Mattke S. i wsp. Hemodynamic deterioration during ICD implant: predictors of high-risk patients. Am. Heart J. 1994; 127: 1064-1067.

23. Adams D.C., Heyer E.J., Emerson R.G. i wsp. Implantable cardioverter-defibrillator: evaluation of clinical neurologic outcome and electroencephalographic changes during implantation. J. Thorac. Cardiovasc. Surg. 1995; 109: 565-573.

24. Birne D., Tung S., Simpson C. i wsp. Complications associated with defibrillation threshold testing: The Canadian experience. Heart Rhythm 2008; 5: 387-390.

25. Hsu J.C., Marcus G.M., Al.-Khatib S.M. i wsp. Predictors of an Inadequate Defibrillation Safety Margin at ICD Implantation Insights From the National Cardiovascular Data Registry. J. Am. Coll. Cardiol. 2014; 64: 256.

26. Bardy G.H., Lee K.L., Mark D.B. i wsp. Sudden Cardiac Death in Heart Failure Trial (SCD-HeFT) Investigators: Amiodarone or an implantable cardioverter-defibrillator for congestive heart failure. N. Engl. J. Med. 2005; 352: 225-237.

27. Moss A.J., Hall W.J., Cannom D.S. i wsp. Multicenter Automatic Defibrillator Implantation Trial Investigators. Improved survival with an implanted defibrillator in patients with coronary disease at high risk for ventricular arrhythmia. N. Engl. J. Med.1996; 335: 1933-1940.

28. Bringole M., Occhetta E., Bongiorni M.G. i wsp. Clinical Evaluation of Defibrillation Testing in an Unselected Population of 2,120 Consecutive Patients Undergoing First Implantable Cardioverter-Defibrillator Implant. J. Am. Coll. Cardiol. 2012; 60: 981-987.

29. Bänsch D., Bonnemeier H., Brandt J. i wsp.; NORDIC ICD Trial Investigators. Intra-operative defibrillation testing and clinical shock efficacy in patients with implantable cardioverter-defibrillators: the NORDIC ICD randomized clinical trial. Eur. Heart J. 2015; 36 : 2500-2507.

30. Russo A.M., Chung M.K. Defibrillation Testing Is Necessary at the Time of Implantable Cardioverter Defibrillator Implantation. Circulation: Arrhythmia and Electrophysiology 2014; 7: 337-346. 